\title{
The Electrophoretic Movement of Proteins from Various Streptomyces Species as a Taxonomic Criterion
}

\author{
By D. GOTTLIEB aNd PAMELA M. HEPDEN \\ Department of Plant Pathology, University of Illinois, Urbana, Ill., U.S.A.
}

(Received 29 November 1965)

\begin{abstract}
SUMMARY
Attempts have been made to use the protein composition of streptomycetes as a criterion in their classification. By using polyacrylamide gel electrophoresis, negatively charged proteins in extracts of various streptomycete strains were separated. For each strain a distinctive. pattern of protein bands was obtained. Protein bands were mapped for a number of strains, including several each of Streptomyces venezuelae and $S$. griseus. Maps were compared and contrasted: in general there was more similarity between strains within one species than between strains of different species. Although the polyacrylamide gel technique cannot yet be used as a major criterion in classification, it can serve, in conjunction with other criteria, as an aid in streptomycete taxonomy.
\end{abstract}

\section{INTRODUCTION}

The taxonomy of Streptomyces is still difficult and often uncertain, but progress is being made to evolve a convenient, workable and comprehensive means of classifying the streptomycetes. Taxonomic criteria such as sporophore morphology, spore wall structure, colour, and utilization of carbon sources are used with moderate success. For examples of this type of characterization see Hesseltine, Benedict \& Pridham (1954), Pridham, Hesseltine \& Benedict (1958), Gottlieb (1959), Pridham (1964), Pridham \& Lyons (1956). Nevertheless, there is still an urgent need for new criteria that might aid in the recognition of species. Recently techniques of polyacrylamide gel electrophoresis have been developed to a point where the separation of proteine in relatively small amounts of extract can be achieved with good reproducibility. Studies on Neurospora crassa and N. sitophila, for example, indicated that mutant strains of these species could be distinguished from the wild type by their protein pattern (Chang, Srb \& Steward, 1962). These intraspecific differences were smaller than interspecific differences. If similar relationships existed among the streptomycetes, the protein patterns could be used to aid in the characterization of species. The work reported in this paper was undertaken to ascertain whether the protein pattern of streptomyces species were stable characteristics of the species, and whether these characteristics were greater than intraspecific differences. 


\section{METHODS}

The cultures used, their source, and the growth media are given in Table 1. One hundred $\mathrm{ml}$. of liquid medium in $500 \mathrm{ml}$. Erlenmeyer flasks were used in all experiments. The streptomycete inoculum and the mycelium to be extracted were always grown in the same type of medium. Each strain was grown and extracted on at least two occasions but usually three times. The inoculum was a $48 \mathrm{hr}$ shaken culture that had been homogenized for 10 sec. in a Waring blendor. Either $0.1 \mathrm{ml}$. or $0.2 \mathrm{ml}$. of the homogenate was added to each flask of fresh medium to grow mycelium for the experiments, and $\mathbf{1 5}$ or more flasks of a strain were used to obtain sufficient mycelium for each experiment. Inoculated flasks were incubated for $48 \mathrm{hr}$ at $25^{\circ}$ on a reciprocal shaker. The mycelium was harvested by centrifugation, washed three times with cold distilled water, and either stored at $-10^{\circ}$ or used immediately.

\section{Table 1. Streptomycetes studied and media on which they were grown}

The composition of the media were:

GA. Glucose asparagine medium: asparagine, 1.0 g.; $\mathrm{K}_{2} \mathrm{HPO}_{4} .3 \mathrm{H}_{2} \mathrm{O}, 4 \cdot 0 \mathrm{~g}$. $; \mathrm{KH}_{2} \mathrm{PO}_{4}$, $0.7 \mathrm{~g}$.; $\mathrm{MgSO}_{4} .7 \mathrm{H}_{2} \mathrm{O}, 2.0 \mathrm{~g}$; glucose, $10.0 \mathrm{~g}$.; distilled water, $1000 \mathrm{ml}$; adjusted to pH $7 \cdot 0$.

SM. Defined medium for S. venezuelae: $\mathrm{KH}_{2} \mathrm{PO}_{4}, 0.7 \mathrm{~g}$.; $\mathrm{K}_{2} \mathrm{HPO}_{4} .7 \mathrm{H}_{2} \mathrm{O}, 4.0 \mathrm{~g}$.; $\mathrm{NaCl}$, 0.3 g.; $\mathrm{MgSO}_{4} .7 \mathrm{H}_{2} \mathrm{O}, 2.0 \mathrm{~g}$; $\mathrm{NaNO}_{3}, 2.0$ g.; glycerol, 10.0 g.; sodium lactate (60\%, $\mathrm{w} / \mathrm{v}), 18.3 \mathrm{~g}$; ; minor elements solution, $1.0 \mathrm{ml}$; ; distilled water, $1000 \mathrm{ml}$.

E. Emerson solution: yeast extract, $1.0 \mathrm{~g}$; ; Bactopeptone, $4.0 \mathrm{~g}$.; beef extract, $4.0 \mathrm{~g}$; sodium chloride, $2.5 \mathrm{~g}$.; cerelose, 10.0 g.; distilled water, $1000 \mathrm{ml}$.

For stock cultures, $2 \%$ agar was included in the medium.

$\begin{array}{lcl}\begin{array}{c}\text { medium. } \\ \text { Strain } \\ \text { designation }\end{array} & \begin{array}{c}\text { Medium } \\ \text { for } \\ \text { stock } \\ \text { cultures }\end{array} & \begin{array}{c}\text { Medium } \\ \text { for } \\ \text { experi- } \\ \text { ments }\end{array} \\ \text { NRRL B 1073 } & \text { GA } & \text { GA, SM, E } \\ \text { NRRL B 2027 } & \text { GA } & \text { GA, SM, E } \\ \text { NRRL B 1076 } & \text { GA } & \text { GA, SM, E } \\ \text { NRRL B 1549 } & \text { E } & \text { GA, SM, E } \\ \text { PD 04833 } & \text { GA } & \text { GA, SM, E } \\ \text { NRRL B 902 } & \text { E } & \text { GA } \\ \text { NRRL B 2277 } & \text { GA } & \text { GA, SM, E } \\ \text { UC 2282 } & \text { GA } & \text { GA, SM, E } \\ \text { UC 2014 } & \text { GA } & \text { GA } \\ \text { NRRL B 2450 } & \text { E } & \text { SM, E } \\ \text { NRRL B 2714 } & \text { E } & \text { SM, E } \\ \text { NRRL B 1793 } & \text { E } & \text { SM, E } \\ \text { NRRL B 1699 } & \text { E } & \text { SM, E }\end{array}$

Streptomyces griseus

S. griseus

S. griseus

S. griseus

S. griseus

S. venezuelae

S. venezuelae

S. venezuelae

S. venezuelae

$S$. orientalis

S. ramulosus

S. antibioticus

Streptoverticillium reticulatum subsp. azocolutum

NRRL B 1793

* Cultures labelled Nrrd were received from Dr T. G. Pridham (Northern Regional Laboratories); those labelled uc from Miss Alma Dietz (The Upjohn Co.) and the one labelled PD from Parke, Davis and Co., Detroit, Mich., U.S.A.

Five g. fresh weight of washed mycelium were ground for at least $7 \mathrm{~min}$. with $10 \mathrm{~g}$. acid-washed sand in a pre-cooled mortar, at $4^{\circ} ; 10 \mathrm{ml}$. cold water were then added gradually and grinding continued for $2 \mathrm{~min}$. more. Sand and large debris were removed by centrifuging at about $2000 \mathrm{~g}$ for $15 \mathrm{~min}$. The supernatant fluid was centrifuged for $1 \mathrm{hr}$ at $100,000 \mathrm{~g}$. Protein in the final supernatant fluid was determined by the method of Lowry, Rosebrough, Farr \& Randall, 1951. For some experiments, cold phosphate buffer $(0.1 \mathrm{M}, \mathrm{pH} \mathrm{7 \cdot 0)}$ was used instead of water. In 
preliminary experiments, extracts were dialysed against water or against $\mathbf{0} \cdot \mathbf{1} \mathrm{M}$ calcium chloride at $4^{\circ}$, but this procedure was abandoned in later experiments.

When the protein in the final supernatant fluid was less than $0 \cdot 85-1 \cdot 0 \mathrm{mg} . / \mathrm{ml}$. the solution was further concentrated. 'Aquacide' (California Corporation for Biochemical Research) was at first used; it removed up to $50 \%$ of the water in $1.5 \mathrm{hr}$, but the resulting protein bands on the stained gels were not sharp. Thereafter, concentration was achieved by leaving the dialysis bags containing extracts in an evacuated desiccator at $4^{\circ}$ overnight.

'Canalco' Model 12 electrophoresis apparatus was used, and ready mixed stock solutions of polyacrylamide gels and of electrophoresis buffer for standard $7 \frac{1}{2} \%$ gels were obtained from Canal Industrial Corporation Ltd. (Bethesda, Md. U.S.A.). The procedure for preparation and polymerization of gels was similar to that described in the Canalco instructions. Glass tubes $6 \mathrm{~cm}$. long with an internal diameter of $0.5 \mathrm{~mm}$. were used to prepare the columns. The lower or separating gel was added first, $0.8 \mathrm{ml}$. to each tube, and these tubes were exposed to a fluorescent lamp for $40 \mathrm{~min}$. Spacer gel, $0.1 \mathrm{ml}$, was then added and the tubes again exposed but for only $15 \mathrm{~min}$. The streptomyces extract was then mixed with the upper gel solution so that there was at least one part gel to one part sample. The protein concentration of the extract had been previously adjusted with water so that 100$200 \mu$ g. protein was applied to each gel column, usually as $0 \cdot 1 \mathrm{ml}$. of gel.

An electrophoresis buffer at $\mathrm{pH} \mathrm{8 \cdot 2-8.5}$ was used and a current of 4-5 mA per tube was applied to the column. The sample front, marked by the bromophenol blue tracking dye, usually reached $\mathbf{0 \cdot 2 5}$ in. from the bottom of the tube in 25-35 min. At this stage, tubes were removed and immediately laid in an ice bath.

Removal of gels. Many gels broke when the recommended reaming needles were used. Instead, the tip of a fine hypodermic needle was ground flat to remove the point and the other end was attached by a Tygon tube to a water source. With water flowing, this needle was carefully inserted between the glass wall and the gel; the needle was turned as it was worked all round the column so that the water stream loosened the gel. This procedure was repeated from the opposite end of the tube and when the gel had loosened from the walls of the tube, it was blown out into water.

The bromophenol blue line marking the electrophoretic front disappeared after the staining and de-staining procedure routinely used. Since this front was used in making measurements of relative mobilities of protein bands, it was essential to know its position. To give reference for all measurements, the unstained gels were always cut at the final position of the tracking dye after their removal from the tubes and before staining them.

Amido black ( $0.5 \%$ in $7 \%$ acetic acid) was used in all experiments as a general protein stain. Washed gels were immersed and shaken in stain for at least $1 \mathrm{hr}$, then de-stained in several changes of $10 \%$ acetic acid until no more dye diffused from the gel. The de-staining was done in small Erlenmeyer flasks on a shaker, during a period of 6-24 $\mathrm{hr}$. Ideally, the protein bands stained dark blue or pale blue in a relatively colourless gel.

No attempt was made to measure the band density quantitatively except to record them as light or dark ( $\mathbf{L}$ or $\mathbf{D})$. The position of the bands was the important criterion. For every gel stained satisfactory, the final protein band positions were 
mapped and measured. Their positions were calculated as the ratio of the distance moved by the protein to the distance moved by the front $\left(E_{F}\right)$. For any series of gels representing one particular streptomycete strain, certain dark stained or wide bands were easily recognizable as identical on all or most gels, with their $E_{F}$ value in good agreement. The identities of some of the bands, particularly the lighter ones, were more difficult to determine, either because their position could not be accurately measured or because they were not consistently present (Table 2). The

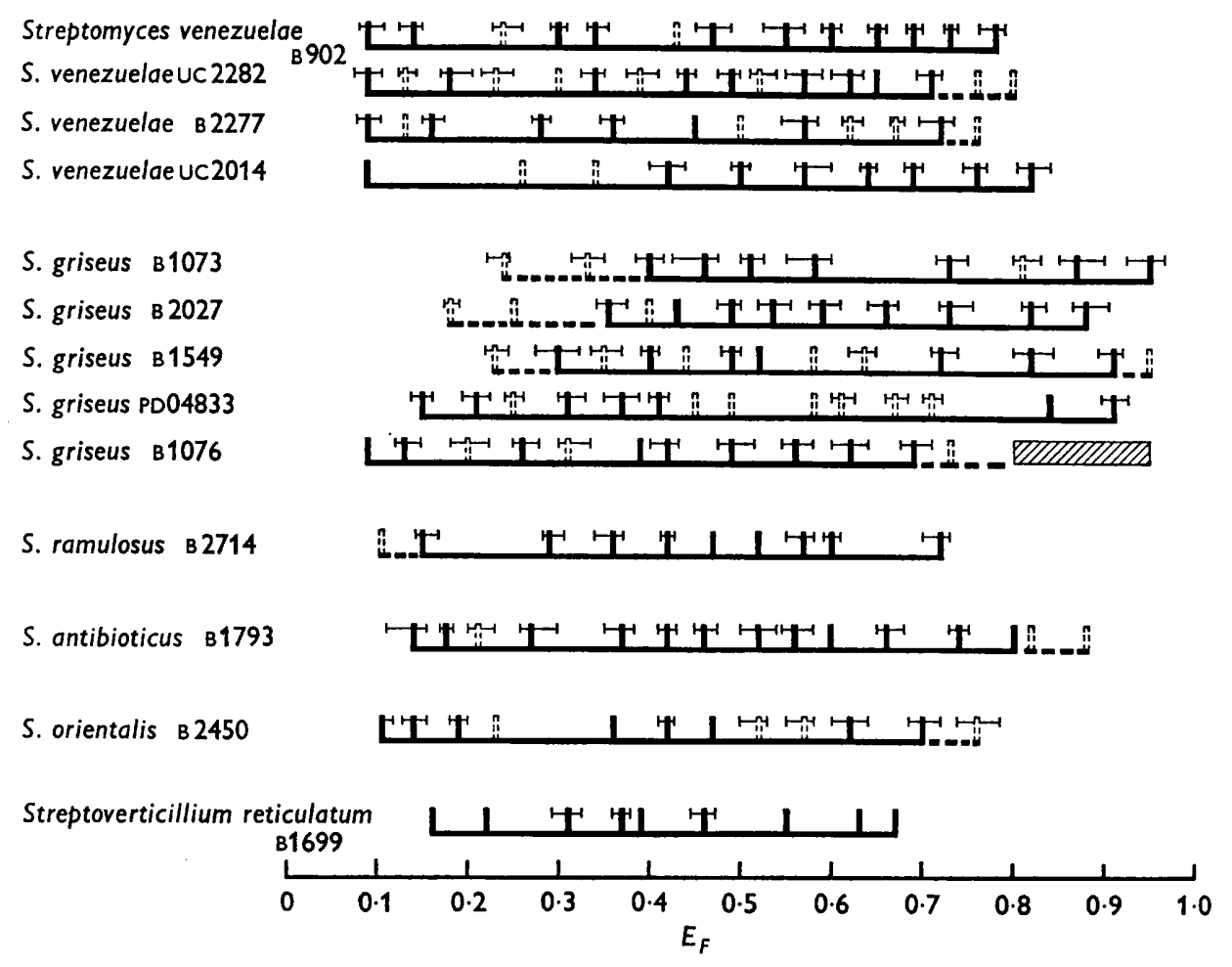

Fig. 1. Profile patterns of all protein bands observed in different species and strains of Streptomyces. The $E_{F}$ values are the average for all experiments and replicates. Broad solid vertical lines represent bands occurring in more than $50 \%$ of the gels. Broken lines represent bands occurring in less than $50 \%$ of the gels. Actual limits of departures from the mean of each band is indicated by thin horizontal lines that cross the mean $E_{F}$ lines of the profiles.

heavy bands were, therefore, used as markers. By knowing the relationship between the position of these light bands and the markers one could ascertain the identity of the light bands. Where there was reasonable agreement within and between experiments, and where a band occurred in more than $50 \%$ of the gels for any one isolate, the band was established. Bands which occurred in less than $50 \%$ of the gels for one strain have also been recorded. These are shown as broken lines in Fig. 1.

This method of recording was used to establish a series of protein bands as typical for each strain. The distribution of protein bands for each strain was plotted as average $E_{F}$ value for each band. Thus one could distinguish established definite bands in a streptomyces isolate from those of more doubtful reliability, i.e. occurring 
in fewer than $50 \%$ of gels, although in good agreement when they did occur. The resulting profile maps of the soluble proteins in various species or isolates could be rapidly compared with each other (Fig. 1).

\section{RESULTS}

The reproducibility of protein bands from any one isolate was generally good. However, the distance moved by the front in a given time varied, even within three replicate tubes of the same experiment. The calculation of the movement of a protein band as the ratio of the movement of the band to that of the front obviated this difficulty.

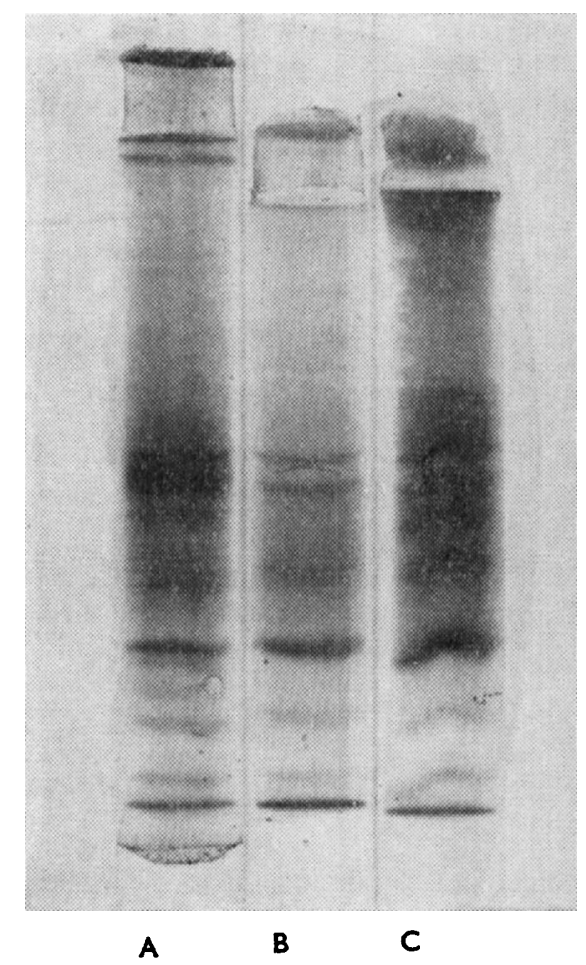

Fig. 2. Stained gels of extracts of Streptomyces griseus в 1078 that were grown and run on separate occasions.

Another problem was that the positions of the fainter bands sometimes could not be accurately measured and therefore were not always consistent, e.g. Table 2, band a. However, the $E_{F}$ values of the main bands were readily measured and in good agreement even when the patterns of the gels did not look alike superficially. Figure 2 shows stained gels from three separate extracts of one strain of Streptomyces griseus NRRL B 1073, run on three separate occasions, A, B and C. Table 2 shows $E_{F}$ values for bands on gels run from extracts of $S$. griseus в 1076 grown at different times. The main bands varied only little when extracts were made of any one isolate grown on different media.

The fresh weight of mycelium varied with the media; that grown in Emerson's 
medium, for example, was as much as 10 times the weight of mycelium from the defined medium, after similar growth periods. Nevertheless, the protein band pattern was not affected by the medium in which the cultures were grown.

The extracts could be stored for at least 7 days in the cold with no apparent change

Table 2. $E_{F}$ values for a series of protein bands resolved on gels from four different extracts of one strain of Streptomyces griseus; strain B 1076

Protein bands

\begin{tabular}{|c|c|c|c|c|c|c|c|c|c|c|c|c|c|}
\hline \multirow{3}{*}{$\begin{array}{c}\text { Extract* } \\
\mathbf{H}\end{array}$} & \multirow{3}{*}{$\begin{array}{l}\text { Replicate } \\
\text { runs† } \\
\text { (i) } \\
\text { (ii) }\end{array}$} & \multicolumn{12}{|c|}{$E_{F}$ value of bands } \\
\hline & & $0 \cdot 10$ & $0 \cdot 13$ & $0 \cdot 18$ & $0 \cdot 25$ & - & - & $0 \cdot 44$ & 0.47 & $0 \cdot 56$ & $0 \cdot 60$ & - & - \\
\hline & & $0 \cdot 10$ & $0 \cdot 15$ & $\mathbf{0 . 2 0}$ & $0 \cdot 27$ & - & $0 \cdot 39$ & $0 \cdot 40$ & 0.50 & 0.57 & - & - & - \\
\hline $\mathbf{K}$ & (i) & $0 \cdot 09$ & $0 \cdot 14$ & - & $0 \cdot 26$ & - & $0 \cdot 39$ & $0 \cdot 4,1$ & 0.51 & $0 \cdot 57$ & - & $0 \cdot 71$ & - \\
\hline \multirow[t]{3}{*}{$\mathbf{Z}$} & (i) & $0 \cdot 10$ & $0 \cdot 12$ & - & $0 \cdot 27$ & $0 \cdot 30$ & $\mathbf{0} \cdot \mathbf{3 8}$ & $0 \cdot 42$ & - & 0.58 & $0 \cdot 64$ & $0 \cdot 70$ & 0.72 \\
\hline & (ii) & - & $0 \cdot 13$ & $0 \cdot 18$ & 0.27 & $\mathbf{0} \cdot \mathbf{3 0}$ & $0 \cdot 39$ & 0.42 & $0 \cdot 48$ & 0.56 & - & 0.70 & - \\
\hline & (iii) & $0 \cdot 09$ & $0 \cdot 12$ & - & 0.25 & - & $\mathbf{0 \cdot 3 8}$ & $0 \cdot 43$ & 0.50 & 0.54 & $0 \cdot 61$ & $0 \cdot 70$ & - \\
\hline \multirow[t]{2}{*}{$\mathbf{A A}$} & (i) & - & 0.12 & $0 \cdot 20$ & $0 \cdot 25$ & - & - & 0.42 & 0.46 & 0.57 & $0 \cdot 64$ & $0 \cdot 68$ & 0.72 \\
\hline & (ii) & - & $0 \cdot 13$ & - & $0 \cdot 26$ & 0.34 & - & 0.40 & 0.51 & 0.55 & $0 \cdot 63$ & $0 \cdot 68$ & 0.72 \\
\hline
\end{tabular}

* Each lettered extract was from $S$. griseus в 1076 grown on different occasions.

$\dagger$ Each run had at least two replicate tubes. - , No band observed in the $E_{F}$ range examined.

Table 3. Average $E_{F}$ values for each protein band observed in various strains of Streptomyces griseus

Strain of S. griseus

$\begin{array}{lccc}\text { B } 1073 & \text { B } 2027 & \text { B } 1549 & \text { PD } 04833 \\ E_{F} \text { value } & & \text { B } 1076\end{array}$

\begin{tabular}{|c|c|c|c|c|c|}
\hline \multirow{2}{*}{$\begin{array}{c}\text { Band } \\
\text { a }\end{array}$} & \multicolumn{5}{|c|}{$E_{F}$ value } \\
\hline & $-*$ & - & - & - & $0.9 \quad(62 \%) \mathrm{D}$ \\
\hline $\mathbf{b}$ & - & - & - & - & $0.13(82 \%) \mathrm{L}$ \\
\hline c & - & - & - & $0.15(100 \%) \mathrm{L}$ & - \\
\hline d & - & $0 \cdot 18(40 \%) \mathrm{L}$ & - & - & - \\
\hline $\mathrm{e}$ & - & - & - & $0.21(55 \%) L$ & $0.20(50 \%) \mathrm{L}$ \\
\hline $\mathbf{f}$ & $0 \cdot 24(36 \%) \mathrm{D} \dagger$ & $0.25(40 \%) \mathrm{D}$ & $0.23(33 \%) \mathrm{D}$ & $0.25(27 \%) \mathrm{D}$ & $0.26(100 \%) \mathrm{D}$ \\
\hline g & $0.33(35 \%) \mathbf{L}$ & - & $0.30(67 \%) \mathrm{L}$ & $0.31(67 \%) \mathrm{L}$ & $0.31(37 \%) \mathrm{L}$ \\
\hline $\mathrm{h}$ & - & $0.36(60 \%) \mathrm{L}$ & $0.35(33 \%) \mathrm{L}$ & $0.37(66 \%) \mathrm{L}$ & $0.39(62 \%) \mathrm{L}$ \\
\hline $\mathbf{i}$ & $0.40(78 \%) \mathrm{D}$ & $0.40(40 \%) \mathrm{D}$ & $0.40(83 \%) \mathrm{D}$ & $0.41(64 \%) \mathrm{D}$ & $0.42(100 \%) \mathrm{D}$ \\
\hline $\mathbf{j}$ & $0.46(78 \%) \mathrm{L}$ & $0.43(60 \%) \mathrm{L}$ & $0.44(50 \%) \mathrm{L}$ & $0 \cdot 45(33 \%) \mathrm{L}$ & - \\
\hline $\mathbf{k}$ & $0.51(78 \%) \mathrm{D}$ & $0.49(60 \%) \mathrm{D}$ & $0.49(83 \%) D$ & $0.49(18 \%) D$ & $0.49(87 \%) \mathrm{D}$ \\
\hline 1 & - & $0.54(80 \%) \mathrm{D}$ & $0.52(66 \%) \mathrm{D}$ & - & - \\
\hline m & $0.58(78 \%) \mathrm{D}$ & $0.59(80 \%) \mathrm{D}$ & $0.58(33 \%) \mathrm{L}$ & $0.58(33 \%) \mathbf{L}$ & $0.56(100 \%) \mathrm{D}$ \\
\hline $\mathbf{n}$ & - & $0.66(100 \%) \mathrm{L}$ & $0.64(50 \%) \mathrm{L}$ & $0 \cdot 61(27 \%) \mathrm{L}$ & $0.62(62 \%) \mathrm{L}$ \\
\hline o & - & - & - & $0.67(45 \%) \mathrm{D}$ & $0.69(75 \%) \mathrm{D}$ \\
\hline $\mathbf{p}$ & $0.73(78 \%) D$ & $0.73(100 \%) \mathrm{D}$ & $0.72(83 \%) D$ & $0.71(27 \%) \mathrm{L}$ & $0.73(37 \%) \mathrm{L}$ \\
\hline$q$ & $0.81(35 \%) \mathrm{L}$ & $0.82(80 \%) \mathrm{L}$ & $0.82(83 \%) \mathrm{L}$ & $0 \cdot 84(82 \%) L$ & - \\
\hline $\mathbf{r}$ & $0.87(85 \%) D$ & $0.88(80 \%) \mathrm{D}$ & - & - & - \\
\hline $\mathbf{s}$ & - & - & $0.91(66 \%) L$ & $0.91(54 \%) \mathbf{L}$ & - \\
\hline $\mathrm{t}$ & $0.95(57 \%) \mathbf{L}$ & - & $0.95(42 \%) \mathrm{L}$ & - & - \\
\hline
\end{tabular}

* The symbol - signifies that no bands were observed in this position.

$\dagger \mathrm{D}$ and $\mathrm{L}$ refer to the intensity of the protein band as dark and light, respectively. Parentheses enclose the percentage of times a band could be observed in gels of all experiments on the isolate. 
in pattern of protein bands. To test for denaturation of proteins, one extract was stored at $4^{\circ}$ and run after 1,3 and 8 days, respectively; there was no change in pattern even after 8 days, provided that bacterial contamination was avoided. In practice, all the runs on any one extract were completed within 3 days. The ability to store these extracts allows the comparison on the same day of cultures harvested at different times.

Other investigators (Chang et al. 1962) have extracted protein from fungi in phosphate buffer (pH 7.0). However, cold distilled water did as well phosphate buffer for these streptomycetes and water at $4^{\circ}$ was routinely used for extraction. Dialysis against water or against salt solutions did not change the protein pattern, so this procedure was discontinued.

Table 4. Average $E_{F}$ values for each protein band observed in strains of Streptomyces venezuelae

Strain of S. venezuelae

\begin{tabular}{|c|c|c|c|c|}
\hline & \multicolumn{4}{|c|}{$E_{F}$ value } \\
\hline $\mathbf{a}$ & $0.09(75 \%) \mathrm{D} \dagger$ & $0.09(80 \%) \mathrm{D}$ & $0.09(75 \%) \mathrm{D}$ & $0.09(100 \%) D$ \\
\hline b & $0 \cdot 14(88 \%) \mathrm{D}$ & $0.13(4.0 \%) \mathrm{L}$ & $0.13(15 \%) \mathrm{L}$ & - \\
\hline c & $-*$ & $0.18(60 \%) \mathrm{L}$ & $0 \cdot 16(75 \%) \mathrm{D}$ & - \\
\hline d & $0 \cdot 24(50 \%) \mathrm{L}$ & $0 \cdot 23(40 \%) \mathrm{L}$ & - & - \\
\hline $\mathrm{e}$ & $0.30(75 \%) \mathrm{L}$ & $0.30(20 \%) \mathrm{L}$ & $0 \cdot 28(63 \%) \mathrm{L}$ & $0.26(20 \%) \mathrm{L}$ \\
\hline f & $0.34(75 \%) \mathrm{D}$ & $0.34(60 \%) \mathrm{D}$ & $0.36(88 \%) \mathrm{D}$ & $0.34(20 \%) \mathrm{L}$ \\
\hline$g$ & - & $0.39(47 \%) \mathrm{L}$ & - & - \\
\hline $\mathrm{h}$ & $0.43(50 \%) \mathrm{L}$ & $0.44(73 \%) \mathrm{D}$ & $0.45(63 \%) \mathrm{D}$ & $0.42(100 \%) \mathrm{D}$ \\
\hline $\mathrm{i}$ & $0.47(75 \%) \mathrm{D}$ & $0.49(53 \%) D$ & $0.50(50 \%) \mathrm{D}$ & $0.50(60 \%) \mathrm{D}$ \\
\hline $\mathbf{j}$ & $0.55(63 \%) \mathrm{L}$ & $0.52(40 \%) \mathrm{L}$ & - & - \\
\hline $\mathbf{k}$ & $0.60(75 \%) \mathrm{D}$ & $0.57(60 \%) \mathrm{D}$ & $0.57(100 \%) \mathrm{D}$ & $0.57(100 \%) \mathrm{D}$ \\
\hline 1 & - & $0.62(60 \%) \mathrm{D}$ & $0.62(50 \%) \mathrm{D}$ & - \\
\hline $\mathrm{m}$ & $0.65(75 \%) \mathrm{D}$ & $0.65(60 \%) \mathrm{D}$ & - & $0.64(100 \%) \mathrm{D}$ \\
\hline $\mathrm{n}$ & $0.69(63 \%) \mathrm{L}$ & - & $0.67(37 \%) \mathrm{L}$ & $0.69(80 \%) \mathrm{L}$ \\
\hline o & $0.73(75 \%) \mathrm{D}$ & $0.71(63 \%) \mathrm{D}$ & $0.72(69 \%) \mathrm{D}$ & - \\
\hline $\mathrm{p}$ & $0.78(63 \%) \mathrm{L}$ & $0.76(50 \%) \mathrm{L}$ & $0.76(47 \%) \mathrm{L}$ & $0.76(80 \%) \mathrm{L}$ \\
\hline$q$ & - & $0.80(33 \%) \mathrm{L}$ & - & $0.82(80 \%) \mathrm{L}$ \\
\hline
\end{tabular}

* The symbol - signifies that no bands were observed in this position.

$\dagger D$ and $L$ refer to the intensity of the protein band as dark and light, respectively. Parentheses enclose the percentage of times a band could be observed in gels of all experiments on the isolate.

A comparison of the $\boldsymbol{E}_{F}$ values of the bands in different isolates of Streptomyces griseus (see Table 3 ) revealed a number of bands common to all or most of the five strains. For example, f, i, $k, m$ and $p$ occurred in all five strains and $g, h, j, n$ and $q$ in four strains. For any named band, the frequency of occurrence and the intensity of staining (dark or light) was not the same for all isolates. The frequency of band $\mathrm{k}$ was low, only $18 \%$ for PD 04833, and high for all other isolates. Band $\mathrm{p}$ was light in PD 04833 and в 1076 but dark in all others. This difference in intensity of colour is related to the concentration of a specific protein in the extract. A few bands have been observed in one or two strains only, e.g. band a. It is reasonable to expect such qualitative and quantitative differences between strains of a species. In four of the isolates there were no bands with $E_{F}$ values less than $\mathbf{0 \cdot 1 5}$ and the upper range varied from 0.88 to 0.95 . Isolate $B$ 1076, however, had some slower moving 
proteins, but none of the faste: moving ones, above $E_{p} \mathbf{0} \cdot 73$. The number of missing bands varied with the isolate. There was good agreement among the $E_{F}$ values (1) in the replicates in one experiment, (2) in repeated studies of the same extract, (3) in different extracts of one isolate, (4) among the different isolates. No one isolate of $S$. griseus contained all the possible bands.

Four isolates of Streptomyces venezuelae were thoroughly tested for the pattern of negatively charged soluble proteins; their $E_{F}$ values and densities, dark or light, are listed in Table 4. The data show that many proteins were common to all the isolates of $S$. venezuelae, bands a, b, e, f, h, i, k, etc. Isolate Uc 2282 contained the greatest number of soluble protein bands; it did not have band $n$ which was present in the other three isolates. Isolate uc 2014 lacked seven bands which were present in UC 2282, whereas B 902 and B 2277 lacked four and five bands, respectively. The movement of the proteins ranged from $E_{F} 0 \cdot 09$ to $0 \cdot 82$.

The band pattern for Streptomyces ramulosus, $S$. antibioticus, $S$. orientalis and Streptoverticillium reticulatum are shown in Fig. 1. Among these three Streptomyces species there is again a distinct and definite distribution of soluble proteins to form a series of bands which are different from other species in the genus. Streptoverticillium reticulatum had a relatively small number of discernible protein bands whose $E_{F}$ values ranged only from $0 \cdot 16$ to $0 \cdot 67$ (Fig. 1).

\section{DISCUSSION}

As with other criteria that have been used in the description of streptomyces, the protein pattern of their extracts cannot be described in absolutes. Many of the protein bands are distinguishable with various degrees of resolution for there is a gradation from those protein bands whose identity is always unmistakable, to others that are too faint to make their identification certain. Even the absolute length of movement may vary from tube to tube in any one experiment. Best of all characteristics is the ratio between the movement of a band and the movement of the front, the $E_{F}$ value.

For all gels from the four extracts of Streptomyces griseus strain B 1076, the variation of $E_{F}$ of a protein band which occurred in all tubes was only slight (see for example, Table 2, band $b$ ). The main source of variation was in the absence of certain bands in some of the replicates, e.g. band $\mathrm{j}$ in Table 2. Even when a band was absent from some tubes, there were bands in other tubes whose $E_{F}$ values were sufficiently alike to indicate that a protein regularly occupied that region (see band $a$ in Table 2). Results from the other strains showed similar departures from the ideal agreement for $E_{F}$ values of all bands. The soluble proteins seem to have relatively fixed $E_{F}$ values under the conditions of the experiment, but many extracts would have to be run to establish this absolute $E_{F}$ value for each protein. The departure from the mean $E_{F}$ value of a band (shown for each band in Fig. 1) never overlapped with any of the other bands for that isolate. This individuality of each band justified considering it a distinct protein.

A survey of the protein band patterns of all the Streptomyces griseus isolates showed that strains B 1073, В 2027 and в 1549 were very similar (see Fig. 1 and Table 3). Their bands ranged from $E_{F} 0 \cdot 15$ to $0 \cdot 95$. On the other hand, strain $\mathbf{B} 1076$ had bands with a very different range of $E_{F}$ values, 0.09-0.74, and also a region of 
diffuse staining with no detectable bands from 0.77 to 0.98 . In strain B 1076, the 'missing' bands were c, $d, j, l, q, r, s$ and $t$; the 'new' bands were $a$ and b. (Lower case letters here refer to Table 3.) This marked difference in protein bands in в 1076 strengthens the separation made by Pridham (1964) when he placed this griseinproducing strain in a subspecies-griseinus. Pridham also classified PD 04833 in another subspecies, $S$. griseus sub.sp. purpureus; however, the protein profile of PD 04833 is not as distinct and more closely resembles the remaining three strains of $S$. griseus than does B 1076.

Among the Streptomyces venezuelae extracts, the profiles of в 902 , Uc 2282 and B 2277 were very similar (see Fig. 1), whereas the strain uc 2014 differed from them in the absence of some bands (see Table 4, bands b, c, d, g, j, l and o). This is puzzling, since strains UC 2014 and в 902 both originated as transfers from $S$. venezuelae U.I. 8-44, more than 15 years ago. Subcultures were sent to different collections but this period was before the freeze-dry storage procedures of today were commonly used, and variation among the subcultures is not unexpected. Both strains are still similar in their own identifying characters. There are of course numerous examples of a change in some strain characteristics with time in culture or storage.

The similarities between patterns of strains of one species are different enough from those of other species to serve as species characteristics. Thus, the protein bands of Streptomyces venezuelae strains all have $E_{F}$ values in the range 0.09-0.82, whereas $S$. griseus isolates (except B 1076) have values 0.15-0.95. Furthermore, no bands have been observed which are common to all strains of both species.

The protein band patterns of Streptomyces orientalis and $S$. ramulosus resemble that of $S$. venezuelae more than $S$. griseus. In addition, $S$. orientalis has some bands in common with $S$. venezuelae uc $\mathbf{2 2 8 2}$. Generally the differences are sufficiently great to distinguish these species from either $S$. griseus or $S$. venezuelae. S. antibioticus and Streptoverticillium reticulatum (Fig. 1) had few bands in common with any other species, and each had $E_{F}$ values in a range distinct from each other and from other species. Their bands thus also could aid in distinguishing them as definite species.

It is obvious that the polyacrylamide gel technique could not be used at present as a general procedure in which all protein bands from one extract were compared with all those from extracts of many other species. It can serve, however, to help separate or identify one streptomycete from another or a few other closely related streptomycetes. For this purpose both the range of $E_{F}$ values and the presence or absence of particular well defined bands could be used.

\section{REFERENCES}

Chang, L. O., Srb, A. M. \& Steward, F. C. (1962). Electrophoretic separation of the soluble proteins of Neurospora. Nature, Lond. 193, 756.

GotTlieb, D. (1959). The Actinomycetes-challenge to the taxonomist. In Lectures on Theoretical and Applied Aspects of Modern Microbiology, 1959-60, pp. 1-19. University of Maryland Publication.

Hesseltine, C. W., Benedict, R. G. \& Pridham, T. G. (1954). Useful criteria for species differentiation in the genus Streptomyces. Ann. N.Y. Acad. Sci. 60, 136.

Lowry, O. H., Rosebrough, N. J., Fark, A. L. \& Randald, R. J. (1959). Protein measurement with the Folin phenol reagent. J. biol. Chem. 193, 265. 
Pridham, T. G. (1964). Taxonomic studies of Streptomyces griseus (Krainsky) Waksman et Henrici, a species comprising many subspecies. Antimicrobial agents and Chemotherapy, 1963, p. 104.

Pridham, T. G. \& Lyons, A. J. (1965). Further taxonomic studies on straight to flexous streptomycetes. J. Bact. 89, 331.

Pridham, T. G., Hesseltine, C. W. \& Benedict, R. G. (1958). A guide for the classification of streptomycetes according to selected groups. Placement of strains in morphological sections. Appl. Microbiol. 6, 52. 